\title{
Researches on the Behaviour of Certain Genotypes of Citrullus lanatus (Thunb.) Mansf. at the Thermic and Hydric Stress Conditions
}

\author{
Maria DUMITRU ${ }^{1 *}$, Gicuta SBIRCIOG ${ }^{1}$, Iuliana MANDRU ${ }^{1}$ and Alina BUZATU ${ }^{1}$ \\ ${ }^{1}$ Research and Development Institute for Vegetable and Flower Growing-Vidra, Romania \\ *)Corresponding author, e-mail: maria.dumitru55@yahoo.com
}

BulletinUASVM Horticulture 72(2) / 2015

Print ISSN 1843-5254, Electronic ISSN 1843-5394

DOI:10.15835/buasvmcn-hort:11469

\begin{abstract}
Seven genotypes of Citrullus lanatus ('De Dăbuleni', 'Dulce de Dăbuleni', 'Oltenia', 'Dochița', 'L-276', 'L-170' and 'Georgel'), in three technological variants (V1- irrigated according plant needs for normal growth and development; V2-50\% of standard irrigation; V3- not irrigated), were tested for the resistance to the thermic and hydric stress, at RDIVFG Vidra. Drought tolerance is determined by anatamo - morphological characteristics of the species (strong root system, leaf sections covered with hairs). In order to obtain rich quality productions watermelon must be cultivated in irrigation conditions in all phenological phases of plants (Ciofu et al., 2003). The yielding capacity of the Citrullus lanatus is influenced by the genotype and the technological conditions (Dumitru et al., 1997). The extreme weather conditions of 2012 created the conditions for genotypes' testing towards the thermal and hydric stress. In these conditions, the phenological phases of plants, yielding capacity and fruits' quality (the soluble dry matter content) were influenced by the technological variant, for all seven genotypes of Citrullus lanatus.
\end{abstract}

Keywords: Citrullus lanatus, genotypes, stress conditions.

\section{Introduction}

Watermelon (Citrullus lanatus) is appreciated for its juicy fruit with sweet and refreshing taste, rich in sugars (7-11\%). Drought tolerance is determined by anatamo - morphological characteristics of the species (strong root system, leaf sections covered with hairs). In order to obtain rich quality productions watermelon must be cultivated in irrigation conditions in all phenological phases of plants (Ciofu et al., 2003). Although it is known as thermophilic species, high temperatures (above $35^{\circ} \mathrm{C}$ ) affect plant growth and development. The water quantity consumed by the vegetable plants during the vegetation period is determined first of all by the level of the perspiration coefficient, by the perspiration productivity, by the water balance and by the consumed water utilization coefficient (Voican V. et al., 1994). The yielding capacity of the Citrullus lanatus is influenced by the genotype and the technological conditions (Dumitru et al., 1997).

\section{Aims}

The paper aims at testing the resistance to the thermic and hydric stress, for seven genotypes of Citrullus lanatus at RDIVFG Vidra.

\section{Materials and Methods}

For assessing the behaviour of the Citrulus lanatus to the abiotic factors, seven genotypes: De Dăbuleni, Dulce de Dăbuleni, Oltenia, Dochița, L-276, L-170 and Georgel. Were studied in three technological variants: V1- irrigated according plant needs for normal growth and development; V2- $50 \%$ of standard irrigation; V3- not irrigated. The crop was planted by seedlings on May 11, 2012. For testing the genotypes at thermic and hydric stress the following observations and 
determinations were made: occurrence of male and female flowers, occurrence of first fruits, yielding capacity and fruits' quality. The results obtained represent average values and the interpretation of the differences' significance was made following the multiple comparison methodDuncan test (Ciulca, 2002).

\section{Results and Discussion}

The climate conditions of 2012 had a special evolution, the levels of precipitations recorded being very different from the normal levels for the southern part of the country. The big quantity of precipitations recorded in May (174.5 l/ $\mathrm{m}^{2}$ ), exceeded by far the multi-annual average of this month which is of $81 \mathrm{l} / \mathrm{m}^{2}$. In the same period the temperatures suddenly decreased, being with $8-10{ }^{\circ} \mathrm{C}$ lower than the multi-annual average of this month. In June the precipitations were of only $21.5 \mathrm{l} / \mathrm{m}^{2}$, distributed in the first part of the month, while in July there were no

Tab.1.The influence of irrigation on the yielding capacity and earliness of watermelon

\begin{tabular}{|c|c|c|c|c|}
\hline \multicolumn{2}{|c|}{$\begin{array}{c}\text { Genotype/ } \\
\text { technological } \\
\text { variant }\end{array}$} & $\begin{array}{l}\text { Yielding } \\
\text { capacity } \\
\text { (t/ha) }\end{array}$ & Signification $^{*}$ & $\begin{array}{c}\text { Date of first } \\
\text { harvesting }\end{array}$ \\
\hline \multirow{3}{*}{$\begin{array}{c}\text { De } \\
\text { Dăbuleni }\end{array}$} & $\mathrm{V}_{1}$ & 60.2 & $\mathrm{a}$ & August 2 \\
\hline & $\mathrm{V}_{2}$ & 32.3 & $\mathrm{~b}$ & August 10 \\
\hline & $\mathrm{V}_{3}$ & 10.5 & $\mathrm{c}$ & September 1 \\
\hline \multirow{3}{*}{$\begin{array}{l}\text { Dulce de } \\
\text { Dăbuleni }\end{array}$} & $\mathrm{V}_{1}$ & 54.5 & $\mathrm{a}$ & August 2 \\
\hline & $\mathrm{V}_{2}$ & 31.5 & $\mathrm{~b}$ & August 10 \\
\hline & $\mathrm{V}_{3}$ & 12.0 & $\mathrm{c}$ & September 1 \\
\hline \multirow{3}{*}{ Oltenia } & $\mathrm{V}_{1}$ & 49.6 & $\mathrm{a}$ & July 30 \\
\hline & $\mathrm{V}_{2}$ & 29.5 & $\mathrm{~b}$ & August 7 \\
\hline & $\mathrm{V}_{3}$ & 10.5 & $\mathrm{c}$ & August 25 \\
\hline \multirow{3}{*}{ Dochița } & $\mathrm{V}_{1}$ & 51.0 & $\mathrm{a}$ & July 15 \\
\hline & $\mathrm{V}_{2}$ & 30.1 & $\mathrm{~b}$ & July 25 \\
\hline & $\mathrm{V}_{3}^{2}$ & 11.5 & $\mathrm{c}$ & August 17 \\
\hline \multirow{3}{*}{ L-276 } & $\mathrm{V}_{1}$ & 53.4 & $\mathrm{a}$ & July 15 \\
\hline & $\mathrm{V}_{2}$ & 30.5 & $\mathrm{~b}$ & July 25 \\
\hline & $\mathrm{V}_{3}$ & 12.5 & $\mathrm{c}$ & August 17 \\
\hline \multirow{3}{*}{ L-170 } & $\mathrm{V}_{1}$ & 48.1 & $\mathrm{a}$ & July 18 \\
\hline & $\mathrm{V}_{2}$ & 23.2 & $\mathrm{~b}$ & July 26 \\
\hline & $\mathrm{V}_{3}$ & 9.3 & $\mathrm{c}$ & August 18 \\
\hline \multirow{3}{*}{ Georgel } & $\mathrm{V}_{1}$ & 55.4 & $\mathrm{a}$ & July 20 \\
\hline & $\mathrm{V}_{2}$ & 33.4 & $\mathrm{~b}$ & July 26 \\
\hline & $\mathrm{V}_{3}$ & 11.5 & $\mathrm{c}$ & August \\
\hline
\end{tabular}

precipitations. Regarding the temperature higher and higher values were recorded from one month to another. During June the maximum values of temperature was over $34^{\circ} \mathrm{C}$, and during July over $35-38^{\circ} \mathrm{C}$ at shade and more then $55^{\circ} \mathrm{C}$ under the sun. Following of high level of precipitation during the May the establishing of seedlings was very high (100\%). The low quantity of precipitations from June-July, doubled by excessively high temperatures, enhanced the drought effect, triggering a significant decrease in the production of variants V2 and V3. In these circumstances, the seven Citrullus lanatus genotypes were influenced by technological inputs. Concerning the date of appearance of the male flowers there weren't significant differences between the variants under study. For the appearance of the female flowers there weren't significant differences between variants $\mathrm{V} 1$ and $\mathrm{V} 2$, but between these two variants and variant V3 the differences were significant. The results are show in table 1.

The content of soluble dry matter of the fruits was also influenced by the technological variant, for all genotypes, being of $11 \%$ at variant V1, of $9.7 \%$ at variant V2 and $6.3 \%$ at variant V3 of De Dăbuleni genotype.

\section{Conclusion}

The extreme weather conditions of 2012 created the conditions for genotypes' testing towards the thermal and hydric stress. In these conditions, the phenological phases of plants, yielding capacity and fruits' quality (the soluble dry matter content) were influenced by the technological variant, for all seven genotypes of Citrullus lanatus.

\section{REFERENCES}

1. Ciofu R, Stan N, Popescu V, Pelaghia Chilom, Apahidean S, Horgoș A, Berar V. Lauer KF, Atanasiu N (2003). Vegetable treaty. Editura Ceres. București.

2. Ciulca S (2002). Experimental tehnique. Editura Mirton. Timișoara.

3. Dumitru M, Diaconescu C (1994). Comparative study of domestic and foreign sources to develop a modern program of improvement watermelon (Citrullus lanatus (Thunb.) onsf.), Analele ICLF Vidra, Vol. XIV, 147-156.

4. 4.Voican,V, Scurtu I, Mirghiș R, Buzescu D (1994). Peculiarities state of drought and its consequences of growing vegetables. Analele ICDLF vol. XIII. 